\title{
Who's On Board? Influence Of Diversity And Network Of Thai Boards Of Directors On Firm Value
}

Thitima Sitthipongpanich, Dhurakij Pundit University, Thailand Piruna Polsiri, Bangkok Metro Public Company Limited, Thailand

\begin{abstract}
Using a large sample analysis of Thai listed firms, we address an important question. Do board diversity and network add value to firms? This article extends the debate on the benefits and costs of board diversity and network and their effect on the broader picture of corporate governance. The sample period straddles 2001 to 2005, which allows us to examine board characteristics in response to the Asian financial crisis. We find that diversity in age and study majors are positively related to Tobin's $Q$ ratio, while diversity in educational levels leads to lower firm value. Our results suggest that boards with diverse age groups and study areas might generate useful advice and complement each other; however, those with diverse educational levels might create costs due to possible conflicts and a lack of coordination and communication. In addition, the results show that alumni networks have a positive effect on Tobin's $Q$ ratio. The findings further suggest that board networks could bring benefits to firms. An alumni network is significant to firms because it could help firms obtain external resources. It also provides significant findings for policy makers to design best practices of directors in emerging countries.
\end{abstract}

Keywords: Diversity; Network; Board of Directors; Firm Value

\section{INTRODUCTION}<smiles>CC1CCCCC1</smiles>
$\mathrm{n}$ a world of increasing globalization, where countries cooperate in order to create even larger economic communities, questions arise as to what are the most important characteristics in determining the success of a firm in a particular market? Given that many countries have different cultural backgrounds and legal frameworks, it is not necessarily going to be the case that the characteristics that guarantee success in one market lead to success in another. However, a common characteristic of many firms is the presence of a board of directors.

A board of directors is one effective governance mechanism, the efficacy of which is widely recognised in both U.S. and non-U.S. models (Globerman, Peng, \& Shapiro, 2011; Hermalin \& Weisbach, 2003; Kaplan \& Minton, 1994; Yermack, 2006). In theory, a board represents all shareholders. It is charged with hiring, monitoring, evaluating, replacing, and advising management to ensure that all managerial decisions maximise shareholder returns. Among these functions, the monitoring and advising functions appear to be the most important (Adams \& Ferreira, 2007; Boone, Field, Karpoff, \& Raheja, 2007; Raheja, 2005). Given the influence that a board of directors has on a firm, and thereby its chances of success, an obvious question is, what characteristics do successful boards share in a particular market?

Because the individuals who constitute boards have a great deal of influence over the decision-making process, shareholders and potential investors need to be aware of, and understand, the various characteristics of the individuals who make up the board. When examining this issue, most existing literature has focused on board composition, in particular the monitoring role of boards in governing management teams based on a principle-agent framework. While board composition is considered an important corporate governance mechanism (Globerman, Peng, \& Shapiro, 2011; Hermalin \& Weisbach, 2003; Kaplan \& Minton, 1994; Yermack, 2006), previous work has 
suggested that other board characteristics such as qualifications and competency of directors, diverse background of directors and the social network of board members are also important during the decision-making process (Espenlaub, Khurshed, \& Sitthipongpanich, 2012; Johnson \& Powell, 1994; Peng, Buck, \& Filatotchev, 2003).

Moreover, Jiang and Peng (2011) suggest that institutions matter in corporate governance. Network is one of the major institutional characteristics in economies with inefficient markets. At the micro-level, network-both political and alumni, for example-could increase firm value; on the other hand, policy makers should be aware of unfair treatments from close connections. At the macro-level, improving resource allocation could help institutional and economic development. We ask whether firms could overcome market inefficiency through informal and private networks of directors.

Detailed board qualifications are omitted in previous research. Moreover, the significant impact of board diversity and network on firm value might explain why board composition has inconclusive effects on firm value (Baliga, Moyer, \& Rao, 1996; Baysinger \& Butler, 1985; Chen, Lin, \& Yi, 2008; Dalton, Daily, Ellstrand, \& Johnson, 1998; Hermalin \& Weisbach, 1991; Kiel \& Nicholson, 2003; Klein, 1998; Mehran, 1995; Peng, 2004; Peng, Buck, \& Filatotchev, 2003). Board composition aspects do not truly reflect directors' experience, knowledge and abilities that contribute to board decision-making process and discussion. The way individual directors generate their views and new ideas could also enhance monitoring and advising effectiveness and are important for firms. To improve corporate governance guidelines on boards of directors, other board attributes, including diversity and network, should be considered.

This study examines how the characteristics of a board influence decision making within a firm. In particular, this paper examines how diversity in the characteristics of a board such as gender, age, educational background, professional expertise and international perspectives affect firm value. On the one hand, it may result in new ideas and skills being brought into the firm, which improve monitoring and advisory efficiency (Anderson, Reeb, Upadhyay, \& Wanli, 2011). On the other hand, a board with highly diverse individuals may experience some coordination and communication problems (Milliken \& Martins, 1996). Additionally, not only does a diverse board bring ideas and skills, but also they bring their social networks of both personal and professional connections. Agrawal and Knoeber (2001), Khwaja and Mian (2005) and Siegel (2007) document, for example, that political networks could help firms obtain external resources such as government concessions; moreover, networks of friends and alumni could provide useful information including opportunities for investment. Nevertheless, Fan et al. (2007) argue that politically connected boards adversely affect firm value and might lead to expropriation problems.

Additionally, the majority of previous studies have analysed boards in developed markets such as the U.S., UK, Japan, Germany, and Australia. Little evidence has been documented on how board characteristics influence the decision making of firms in emerging markets, such as those in Asia. This study aims to redress this balance in part by using the experience of Thailand as an example. The 1997 Thai economic meltdown had been perceived as the origin of the whole Asian region's financial failure, indicating that more understandings about Thai firms are needed (Peng, Au, \& Wang, 2001). Moreover, institutional settings in which corporate governance is embedded are different between developed and emerging markets (Claessens, Djankov, \& Lang, 2000; Globerman, Peng, \& Shapiro, 2011; La Porta, Lopez de Silanes, \& Shleifer, 1999). Furthermore, a single country study provides a unique analysis because the influence of board of directors can vary under different legal systems, institutional settings, and governance frameworks (Filatotchev, Jackson, \& Nakajima, 2012).

This study aims to make a number of contributions. First, in addition to examining board composition, an area that has already been extensively studied, we examine how diversity in gender, age, educational background, professional expertise, and international perspectives affect firm value. To the best of our knowledge, this article is the first to provide new evidence to show the influence of board diversity and network on firm value in Asia. Second, we extend the research done by Choi et al. (2007), who focus on the role of outside independent directors as a mechanism of corporate governance in response to the regulatory reform after the Asian financial crisis. We extend their paper by looking at the characteristics of Thai boards in response to public attention of good governance practices, e.g., director qualifications, board diversity and network, and board composition in the wake of the Asian financial crisis. Finally, networks are found to be one of the key institutional characteristics in Asia (Bunkanwanicha \& Wiwattanakantang, 2009; Espenlaub, Khurshed, \& Sitthipongpanich, 2012; Peng, Au, \& Wang, 2001; Siegel, 
2007). In Thailand, Peng et al. (2001) find that military directors are significant to multinational firms. This article differs from Peng et al. (2001) in that proxies of networks combine both political connections, namely ex-military and ex-bureaucrats, and university alumni networks. The remainder of this article begins with backgrounds of corporate governance in Thailand, followed by hypotheses, methods, findings, and conclusion.

\section{CORPORATE GOVERNANCE ON BOARD OF DIRECTORS IN THAILAND}

The Public Company Act B.E. 2535 (C.E. 1992) of Thailand requires that a board has at least five members. A company can set the appropriate board size in its articles of association. However, at least half the directors must reside in Thailand. The SET has been promoting good corporate governance for listed firms since before the Asian financial crisis. In 1996, it issued a listing requirement indicating that all listed companies have at least two independent directors. In early 1998, in response to the crisis, it required that listed companies have an audit committee to ensure the quality, credibility, and objectivity of their financial reports and internal control system. Later in 1998, the SET issued the Code of Best Practice for Directors of Listed Companies that outlines board composition, roles and responsibilities of directors, appointments to the board, directors' remuneration, board and shareholders' meetings, and reports. Interestingly, no guidelines on director characteristics or qualifications such as background, skills, experience, and expertise have been specified in the corporate governance guidelines.

In 2002, the SET announced the Principles of Good Corporate Governance that describe the structure, roles, duties, responsibilities, and independence of boards of directors. Independent directors should constitute onethird of the total directors with a minimum of three independent directors on the board. The qualifications of independent directors should be held to the same standard as the qualifications for those of the audit committee members. In a company that has dominant shareholders, there should be directors who represent a fair proportion of each group's investment. Moreover, a clear separation should exist between power and authorities in such a way that unlimited power is not granted to one person. However, a company may combine the titles of chairman of the board and president into one position, or keep them as two separate positions. In the latter case, an independent director is entitled to be appointed as the chairman. In 2006, the revised version of Principles of Good Corporate Governance added the principles about the structure of the board of directors. That is, a board should consist of directors with various skills, experience, and expertise that are useful to the company.

Also in 2006, the Thai Institute of Directors Association issued Director Nomination Best Practices, which recommend specific board competencies and director qualifications. A board of directors must excel in initiating corporate strategies and policies and implementing them effectively. To enhance board competencies, the following business competencies should be considered when selecting qualified candidates for board positions. These competencies include accounting and finance, organization and human resources management, risk management, crisis management, industry knowledge, international marketing, strategic planning, and others that the committee deems necessary for the next three to five years such as e-commerce applications, research and development, and merger and acquisition. Besides board competencies and directors' characteristics, the diversity and balance of a board are also considered in the Best Practices. For example, board members may represent various stakeholders and have different personal and professional experience, backgrounds, and other characteristics.

\section{HYPOTHESES}

\section{Board Diversity and Firm Value}

After the Asian financial crisis, the Principles of Good Corporate Governance acknowledged the importance of diverse backgrounds and qualifications of directors. Moreover, according to the resource dependence theory, directors with diverse backgrounds and influential networks could acquire external resources and bring various skills and knowledge to benefit firms (Pfeffer, 1972; Pfeffer \& Salancik, 1978). Therefore, we expect that board diversity is beneficial to firms.

\section{Gender}

Gender diversity represents differences in perspectives that individuals bring to their work situations or environment (Adams \& Ferreira, 2009; Cox, Lobel, \& McLeod, 1991). In a boardroom, appointing women directors 
can provide different points of view and problem solving attributes to board discussions and supervision (Letendre, 2004). In addition, adding female directors could lower excessive risk taking in strategic decision making because women tend to be more risk averse (Byrnes, Miller, \& Schafer, 1999; Eckel \& Grossman, 2008; Jianakoplos \& Bernasek, 1998) and less overconfident (Barber \& Odean, 2001; Lenney, 1977) than men. The positive impact of female directors on firm performance and value is empirically investigated by several studies. Carter, Simkins, \& Simpson (2003) and Campbell \& Mínguez-Vera (2008) find that gender diversity among board members positively affects firm value. Likewise, Erhardt, Werbel, \& Shrader (2003) and Bonn (2004) report that a higher proportion of female directors increases firm performance. Along the same line, Kang, Ding, \& Charoenwong (2009) find positive investors' reactions to the appointment of female directors. From the view that female directors bring different ideas and attributes to board discussions and provide additional board monitoring, gender diversity on boards benefits the firms. We hypothesize that a higher proportion of female directors increases firm value. Therefore:

Hypothesis 1: Diversity in gender has a positive impact on firm value.

Age

Director experience, maturity, and background generally increase with age (Bilimoria \& Piderit, 1994). Age diversity among directors potentially brings in a greater variety of ideas in a boardroom. For example, older directors may provide greater steadiness and experiential acumen to board discussions. Younger directors, on the other hand, may bring greater dynamics and less conservativeness to board decision making (Anderson, Reeb, Upadhyay, \& Wanli, 2011). Furthermore, older directors tend to be more psychologically committed to the company, while younger directors are superior in terms of grasping new ideas and learning new things (Koufopoulos, Zoumbos, Argyropoulou, \& Motwani, 2008). Regarding how age diversity in boardrooms affects performance, Hagendorff \& Keasey (2012) document that director age diversity increases merger returns in the banking industry. McIntyre \& Mitchell (2004) find a positive effect of the variation in director age on firm performance. Therefore:

Hypothesis 2: Diversity in age has a positive impact on firm value.

\section{Educational Levels}

Education shows the level of knowledge and skill base of an individual, which are significant during decision-making processes (Bhagat \& Black, 1999). Hillman \& Dalziel (2003) document that board knowledge could help firms obtain external resources and affect firm performance. Anderson, Reeb, Upadhyay, \& Wanli, (2011) find that diverse educational backgrounds of directors contribute to higher firm value. They argue that heterogeneity of boards of directors brings benefits to firms because directors with diverse backgrounds would complement each other in advising and monitoring top managers, hence increasing firm value. As noted by prior research, the educational level indicates an individual's knowledge base and intellectual ability. A director could use his/her educational knowledge to come up with distinctive perspectives and innovative ideas in advising the management team. It is expected that a board of directors with diverse educational levels could provide applicable and constructive advice to boards, thus resulting in higher firm value. Therefore:

Hypothesis 3: Diversity in educational levels has a positive impact on firm value.

\section{Study Majors}

Study majors of directors potentially provide greater knowledge and understanding to develop firm strategies and are found to have an effect on firm performance. In particular, professional management degrees educate directors to become organizers and problem solvers. Hsu (2010) finds that board quality as measured by the percentage of directors with a business degree is positively related to firm performance. Yermack (2006) also finds that business knowledge of directors is useful to companies and affects firm value. In addition, Agrawal \& Knoeber (2001) document that directors with educational backgrounds in law are commonly found in firms whose political connections to the government are needed for firm operations. Various academic majors of directors likely provide managers with broader advice, consistent with the findings of Kim \& Lim (2010). They document that diversity in study areas is positively related to Tobin's $Q$ ratio. Therefore: 
Hypothesis 4: Diversity in study majors has a positive impact on firm value.

\section{Expertise}

Expertise represents abilities and competence of directors. The functional background of directors could bring useful and practical ideas. It is possible that the expertise diversity of directors will provide wider and deeper views to monitor and advise the management team. Anderson, Reeb, Upadhyay, \& Wanli (2011) find that board experience heterogeneity is positively related to Tobin's Q ratio. Hagendorff \& Keasey (2012) also find that the diversity of directors' occupations leads to higher merger returns, thus creating value to shareholders. A board of directors could effectively perform as a result of the presence of diverse functional knowledge and skills of directors. A diversity of talented members could allow firms to obtain different external resources. Using their area of expertise, directors can contribute ideas and share their experience in board meetings. It is expected that the expertise of directors matters to firms and will increase the effectiveness of boards and possibilities to obtain external resources, thus leading to higher firm value. Therefore:

Hypothesis 5: Diversity in expertise has a positive impact on firm value.

\section{International Perspectives}

International perspectives provide CEOs with knowledge and confidence to understand how to do businesses in diverse environmental settings (Herrmann \& Datta, 2002). Previous evidence shows that international experience of CEOs has a positive impact on foreign market entry decision. Norburn (1986) also documents that international exposure and linguistic ability of directors are positively associated with industry average performance. Directors with international experience could increase creativity and provide diverse and wider perspectives to the decision-making process of firms (Leblanc \& Gillies, 2005). We hypothesize that directors graduated from abroad are expected to have wider viewpoints and to conform to the international environment, which might bring higher competitive advantages over their local rivals. Therefore, it is expected that directors with international perspectives could bring higher benefits, hence increasing firm value.

Hypothesis 6: Diversity in international perspectives has a positive impact on firm value.

\section{Board Networks and Firm Value}

Director's abilities to connect with external resource providers are important to establish strong interorganizational ties. Networks, that is, the connections of directors, are recognized to potentially affect the perception and the decision-making process of directors. Nicholson \& Kiel (2007) describe that the social network of directors increases firm value. Information that is influential to board decision making could be accessed through social networks.

\section{Political Connections}

Political connections are found to be related to firm performance. The relationship between outside directors with government experience and firm value is positively significant (Kim \& Lim, 2010). The experience of retired bureaucrats is considerably useful in some industries, and firms that deal with the government generally appoint ex-bureaucrats as their directors (Agrawal \& Knoeber, 2001; Miwa \& Ramseyer, 2005). Military directors are essential to business internationalization (Peng, Au, \& Wang (2001). In addition, political connections could influence government owned banks to lend to firms that have a politician on their boards of directors (Khwaja \& Mian, 2005). Therefore:

Hypothesis 7: Political connections of directors have a positive impact on firm value.

\section{Alumni Networks}

Networking abilities of management team members improve agenda setting and generate strategic alternatives (Kauer, Prinzessin zu Waldeck, \& Schaffer, 2007). Directors, who maintain their networks with their 
company's stakeholders, often obtain new and different knowledge, hence providing benefits during strategic decision-making processes. Connected directors may access information from the network. They can apply knowledge and experience to provide better strategic advice and to competently discuss related matters in board meetings (Carpenter \& Westphal, 2001). Previous work shows that social networks are also significant for business expansion. Palmer \& Barber (2001) show that the presence of well-networked top managers is positively associated with the likelihood of the achievement of corporate acquisition. CEOs, who are usually members of elite graduate schools of business and social clubs, are expected to pursue acquisition activities. Siegel (2007), notably, finds the impact of a CEO's or chairman's network on forming cross border alliances. Directors graduated from elite universities are expected to be socially united because of strong ties among alumni and a long history of their institutions. Directors who are tied to such social networks are believed to obtain useful information because of lower asymmetric information among network members. The relations among network members could facilitate connected directors to extend relations to other stakeholders of firms. Such linkages can obviously help firms in accessing potential markets and finding financial or strategic partners. As a result, connected directors would be able to bring higher financial benefits to firms. Therefore:

Hypothesis 8: Alumni networks of directors have a positive impact on firm value.

SAMPLE, DATA AND METHODOLOGY

\section{Sample}

Sample firms are non-financial firms listed on the SET, covering the period of 2001 to 2005. This sample period reflects the consequences of one of SET's best practice responses to the financial crisis in 1997, which was to promote professionalism through the training of directors of Thai listed firms. In addition, the period highlights the foresight of listed firms and policy makers in improving corporate governance concerning boards of directors.

The information used to define board characteristics is publicly available from the SET. We focus only on director data, which are provided in Form 56-1, which the Stock Exchange of Thailand requires all listed firms to submit. In addition, financial data are collected from the SETSMART database, which compiles company information of Thai firms listed in the SET. In this study, all financial data are winsorized at $1 \%$ and $99 \%$.

\section{Board Characteristics and Composition}

We obtained director biographies, including gender, age, educational background, and previous work experience over the previous five years (or more). The individual director data are quantified and aggregated for the whole board to describe the characteristics of a board of directors. Then we define board diversity and network. Board diversity is classified into six groups: gender, age, educational levels, study majors, expertise, and international perspectives. Board network is classified into two groups: political connections and alumni networks.

Regarding variables in director characteristics, gender diversity is measured by the ratio of the number of female directors to the total number of directors. Diversity measures of age, educational levels, study majors, and expertise are defined by a modification of the Herfindahl Index (HHI). HHI is a concentration measure, while our modified index is a measure of diversity, which is also applied by Hagendorff and Keasey (2012) and Kim and Lim (2010).

Age of directors is divided into five age cohorts: less than 30 years old, 31-40 years old, 41-50 years old, 51-60 years old, and greater than 60 years old. Diversity in age is defined as follows:

Diversity in age $\mathrm{i}_{\mathrm{i}, \mathrm{t}}=1-\left[\sum_{g=1}^{n}\left(\frac{A g e_{g}}{\text { Total number of directors }}\right)^{2}\right]_{i, t}$

where $A g e_{g}=$ the number of directors in each age cohort $(\mathrm{g})$. 
The educational levels are categorized into the four highest educational levels, i.e., below bachelor's, bachelor's, master's, and doctoral degrees. The variable of the educational levels is defined as a percentage of directors with each of the highest degree level within a board of directors. Diversity in educational levels is defined as follows:

Diversity in educational levels $\mathrm{i}_{\mathrm{i}, \mathrm{t}}=1-\left[\sum_{g=1}^{n}\left(\frac{E d u_{g}}{\text { Totalnumber of directors }}\right)^{2}\right]_{i, t}$

where $E d u_{g}=$ the number of directors in each category of educational levels.

We also classify different knowledge bases into six study areas: 1) accounting/finance/economics, 2) business-related knowledge, 3) law, 4) engineering/science, 5) medicine, and 6) others. ${ }^{1}$ Diversity in study majors is defined as follows:

Diversity in study majors $\mathrm{i}_{\mathrm{t}, \mathrm{t}}=1-\left[\sum_{g=1}^{n}\left(\frac{\text { Major }_{g}}{\text { Totalnumber of studymajors of all directors }}\right)^{2}\right]_{i, t}$

where Major $_{g}=$ the number of majors held by all directors in each study area.

Work experience of directors is divided into seven areas of expertise: 1) accounting/finance/economics, 2) business, 3) law, 4) engineering/science, 5) medicine, 6) academic professor, and 7) others. ${ }^{2}$ Diversity in expertise is defined as follows:

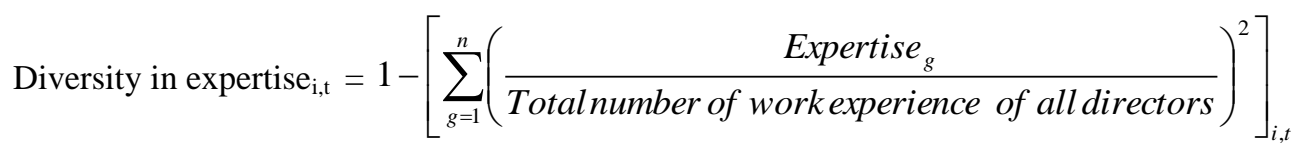

where Expertise $_{g}=$ the number of work experience held by all directors in each area of expertise.

The variable of diversity in international perspectives of directors is defined as the ratio of the number of directors graduated from abroad to the number of directors graduated from local institutions. ${ }^{3}$

Network variables are defined to demonstrate director abilities in seeking and obtaining external resources and information from their social networks. We define political connections as a dummy variable that is equal to 1 if there is a former government, police, or military officer on board, and zero otherwise. The alumni network variable is defined as a proportion of directors who graduated from Chulalongkorn University, which is the most elite and longest established university in Thailand. ${ }^{4}$

Considering board composition, board size is defined as the number of directors. Board independence is measured by the fraction of independent directors. CEO duality is a dummy variable equal to 1 if the CEO also holds the position of chairman of the board, and zero otherwise.

\footnotetext{
${ }^{1}$ The Type 2 knowledge base is defined to capture the effect of business-related degrees, which are excluded from Type 1.

${ }^{2}$ We use pairwise correlation analysis to test whether variables of diversity in study majors and diversity in expertise are highly correlated. We find that these two independent variables are not significantly correlated.

${ }^{3}$ If a director is graduated from a local institution and an institution outside Thailand, we report that he/she is in international perspectives group.

${ }^{4}$ Chulalongkorn University was established on 26 March 1916 as the first university in Thailand. Because of the long history of the university, graduates of this institution could be linked in extensive social networks and are considered as graduates from the most prestigious university.
} 


\section{Methodology}

This study provides three empirical analyses. First, we present descriptive analyses of board characteristics of Thai listed firms over a period of five years after the Asian financial crisis. In the second part, we compare financial characteristics between two groups using equality tests of mean values. Sample firms are categorized by diversity and network measures. In the last section, we investigate the impact of board diversity, network, and composition on firm value, using a regression analysis. The model is controlled by industry and year effects as follows:

$$
\begin{aligned}
\text { Firmvalue }_{i, t} & =\alpha_{i, t}+\beta_{1} \text { Gender }_{i, t}+\beta_{2} \text { Age }_{i, t}+\beta_{3} \text { Edu }_{i, t}+\beta_{4} \text { Major }_{i, t}+\beta_{5} \text { Expertise }_{i, t}+\beta_{6} \text { Inter }_{i, t} \\
& +\beta_{7} \text { PolCon }_{i, t}+\beta_{8} \text { Alumni }_{i, t}+\beta_{9} \text { BoardSize }_{i, t}+\beta_{10} \text { Independence }_{i, t}+\beta_{11} \text { Duality }_{i, t} \\
& +\beta_{12} \text { Size }_{i, t}+\beta_{13} \text { Leverage }_{i, t}+\beta_{14} \text { Firmage }_{i, t}+\beta_{15} \text { Sales growth }_{i, t}+\beta_{16} \text { Ind }_{i, t}+\beta_{17} \text { Year }_{i, t}+\varepsilon_{i, t}
\end{aligned}
$$

Firm value is measured by the market to book ratio (a proxy of Tobin's Q ratio), which is the ratio of market value of total assets to book value of total assets. Our main independent variables include board diversity and network as discussed in the previous section. We also introduce several variables into our analysis to control for board composition and firm characteristics. Firm characteristics include size (proxied by the log of sales), leverage (proxied by the ratio of total debt to total assets), firm age (proxied by the number of years since establishment), and sales growth (proxied by the annual change in sales).

\section{FINDINGS}

\section{Board and Firm Characteristics of Thai Listed Firms}

Descriptive statistics of board and firm characteristics are provided in Tables 1 and 2, respectively. There are 1,285 firm-year observations in total, covering the period of 2001-2005. Table 1 shows that gender diversity is low in Thai boardrooms. Only about $16 \%$ of total directors are female. The average age of directors is roughly 55 years old. When separating director age into five cohorts, we find that directors who are in the range of 51-60 years old are appointed most often. As for age diversity measure, the mean value is 0.59 (median, 0.62), while the highest value is 0.78 . Regarding educational levels of directors, almost $10 \%, 40 \%$ and $37 \%$ of directors have the highest degree of a doctoral, master's, and bachelor's degree, respectively. Diversity in educational levels is similar to diversity in age. Specifically, the average diversity index is 0.57 (median, 0.59 ) and the maximum is 0.75 . The results of study majors of directors show that business administration is the most frequently found academic major on the board. Diversity measure of educational majors appears to be higher than that of educational levels. More precisely, the mean value of diversity measure of study majors is 0.65 (median, 0.68 ) with the maximum value of 0.82. As expected almost all firms have a director with some business expertise. Compared with other diversity indices, expertise diversity index is the lowest. The average is 0.4 (median, 0.42 ) and the highest is 0.79 . As a diversity measure of international perspectives, the average ratio of the number of directors with international education to the number of directors with local education is 2.13 (median, 1.4). Considering networks of boards of directors, approximately $70 \%$ of the sample firms appoint former bureaucrats as the directors, while about $15 \%$ of the directors are alumni of Chulalongkorn University. 
Table 1: Descriptive Statistics of Board Characteristics and Composition

\begin{tabular}{|c|c|c|c|c|c|}
\hline Variables & Mean & Standard Deviation & Median & Min & Max \\
\hline \multicolumn{6}{|l|}{ Board Characteristics } \\
\hline \multicolumn{6}{|l|}{ Gender: } \\
\hline Percentage of firms with female directors & 78.21 & - & - & - & - \\
\hline Percentage of Female directors & 16.22 & 14.16 & 13.64 & 0 & 75.00 \\
\hline \multicolumn{6}{|l|}{ Age: } \\
\hline Average age of directors & 55.52 & 4.78 & 55.67 & 40.08 & 70.17 \\
\hline \multicolumn{6}{|l|}{ No. of directors who are } \\
\hline - Less than 30 years old & 0.11 & 0.36 & 0 & 0 & 3 \\
\hline - 31-40 years old & 0.86 & 1.05 & 1 & 0 & 6 \\
\hline - 41-50 years old & 2.70 & 1.84 & 2 & 0 & 11 \\
\hline - 51-60 years old & 4.07 & 2.47 & 4 & 0 & 18 \\
\hline - Older than 60 years old & 3.71 & 2.67 & 3 & 0 & 12 \\
\hline \multicolumn{6}{|l|}{ Percentage of firms with directors who are } \\
\hline - Less than 30 years old & 8.95 & - & - & - & - \\
\hline - 31-40 years old & 52.61 & - & - & - & - \\
\hline$-41-50$ years old & 91.91 & - & - & - & - \\
\hline - 51-60 years old & 95.88 & - & - & - & - \\
\hline - Older than 60 years old & 91.21 & - & - & - & - \\
\hline Diversity in age & 0.59 & 0.11 & 0.62 & 0 & 0.78 \\
\hline \multicolumn{6}{|l|}{ Educational Levels: } \\
\hline \multicolumn{6}{|l|}{ Percentage of directors who have } \\
\hline - Below bachelor's degree & 14.04 & 14.41 & 10.00 & 0 & 87.50 \\
\hline - Bachelor's degree & 36.77 & 19.11 & 36.36 & 0 & 92.86 \\
\hline - Master's degree & 39.37 & 19.45 & 37.50 & 0 & 100 \\
\hline - Doctoral degree & 9.81 & 10.91 & 8.33 & 0 & 66.67 \\
\hline Diversity in educational levels & 0.57 & 0.11 & 0.59 & 0 & 0.75 \\
\hline \multicolumn{6}{|l|}{ Study Majors: } \\
\hline \multicolumn{6}{|l|}{ No. of directors whose study major is } \\
\hline - Accounting, finance, or economics & 2.82 & 2.21 & 2 & 0 & 16 \\
\hline - Business administration & 3.43 & 2.36 & 3 & 0 & 13 \\
\hline - Law & 0.79 & 1.05 & 0 & 0 & 8 \\
\hline - Engineering or science & 2.86 & 2.97 & 2 & 0 & 30 \\
\hline - Medicine & 0.37 & 1.26 & 0 & 0 & 11 \\
\hline \multicolumn{6}{|l|}{ Percentage of firms with directors whose study major is } \\
\hline - Accounting, finance, or economics & 88.02 & - & - & - & - \\
\hline - Business administration & 92.68 & - & - & - & - \\
\hline - Law & 49.88 & - & - & - & - \\
\hline - Engineering or science & 82.80 & - & - & - & - \\
\hline - Medicine & 15.33 & - & - & - & - \\
\hline Diversity in study majors & 0.65 & 0.13 & 0.68 & 1 & 0.82 \\
\hline \multicolumn{6}{|l|}{ Expertise: } \\
\hline \multicolumn{6}{|l|}{ Percentage of firms with directors whose expertise is } \\
\hline - Accounting, finance, or economics & 59.61 & - & - & - & - \\
\hline - Business administration & 98.99 & - & - & - & - \\
\hline - Law & 21.25 & - & - & - & - \\
\hline - Engineering or science & 35.64 & - & - & - & - \\
\hline - Medicine & 28.72 & - & - & - & - \\
\hline - Academics & 8.16 & - & - & - & - \\
\hline Diversity in expertise & 0.40 & 0.20 & 0.42 & 0 & 0.79 \\
\hline \multicolumn{6}{|l|}{ International Perspectives: } \\
\hline $\begin{array}{l}\text { Percentage of firms with directors who have international } \\
\text { education }\end{array}$ & 61.09 & - & - & - & - \\
\hline Diversity in international perspectives & 2.13 & 2.36 & 1.4 & 0 & 18 \\
\hline
\end{tabular}


Table 1 cont.

\begin{tabular}{|c|c|c|c|c|c|}
\hline Political Connections: & Mean & Standard Deviation & Median & Min & Max \\
\hline $\begin{array}{l}\text { Percentage of firms with directors who are a former } \\
\text { government, police or military officer }\end{array}$ & 68.79 & - & - & - & - \\
\hline \multicolumn{6}{|l|}{ Alumni Networks: } \\
\hline $\begin{array}{l}\text { Percentage of directors who are alumni of Chulalongkorn } \\
\text { University }\end{array}$ & 15.27 & 16.90 & 11.11 & 0 & 90.00 \\
\hline \multicolumn{6}{|l|}{ Board composition } \\
\hline \multicolumn{6}{|l|}{ Size: } \\
\hline No. of directors on board & 11.44 & 3.20 & 11 & 5 & 25 \\
\hline \multicolumn{6}{|l|}{ Independence: } \\
\hline Percentage of executive directors & 42.09 & 17.27 & 42.86 & 5.26 & 81.25 \\
\hline Percentage of non-executive directors & 26.42 & 18.97 & 25.00 & 0 & 78.95 \\
\hline Percentage of independent directors & 31.49 & 9.61 & 30.00 & 12.00 & 83.33 \\
\hline \multicolumn{6}{|l|}{ CEO Duality: } \\
\hline Percentage of firms with CEO duality & 23.35 & - & - & - & - \\
\hline
\end{tabular}

Note: Dummy variables are reported in the unit of percentage.

In terms of board composition, the results show that the average number of directors on board is around 11. Independent directors account for about one third of total directors, which is consistent with the regulation by the SET. When considering the fraction of external directors (i.e., independent and non-executive directors), these directors consist of roughly $60 \%$ of total board seats, which is the majority of the board. We also find that almost one quarter of Thai companies combine the CEO and chairman positions.

Firm characteristics of our sample are provided in Table 2. On average, the sample firms have been established for about 25 years. The mean value of total assets of the sample firms is around 233 million USD, while the average market capitalization is around 168 million USD. The mean value of sales is 176 million USD with the average sales growth of nearly $20 \%$. Considering financial leverage, the firms have the average ratio of total debt to total assets of $25 \%$. As for firm value, the average Tobin's Q ratio is 1.2.

Table 2: Descriptive Statistics of Firm Characteristics

\begin{tabular}{|l|c|c|c|c|c|}
\hline \multicolumn{1}{|c|}{ Variables } & Mean & Standard deviation & Median & Min & Max \\
\hline Firm age (years) & 25.50 & 14.72 & 22.92 & 1.47 & 129 \\
\hline Total assets (million USD) & 232.99 & 554.97 & 58.65 & 7.37 & $4,007.86$ \\
\hline Market capitalization (million USD) & 167.97 & 440.49 & 36.50 & 1.43 & $3,090.80$ \\
\hline Sales (million USD) & 175.99 & 426.37 & 53.78 & 2.05 & $3,081.99$ \\
\hline Sales growth (\%) & 19.69 & 47.85 & 10.46 & -45.65 & 329.70 \\
\hline Debt to assets (\%) & 25.07 & 21.08 & 22.13 & 0.00 & 78.85 \\
\hline Tobin's Q ratio & 1.213 & 0.656 & 1.022 & 0.430 & 4.599 \\
\hline
\end{tabular}

Note: The Bank of Thailand's foreign exchange reference rate is 41.91 baht per one US dollar over a period of 2001-2005. 
Table 3: Differences in Financial Characteristics: The Matter of Diversity and Network

The figures are shown separately for different diversity and network characteristics. Asterisks indicate the statistical significance of the difference between two groups of firms; significance levels of at least $1 \%(* * *), 5 \%(* *)$ and $10 \%(*)$ are reported.

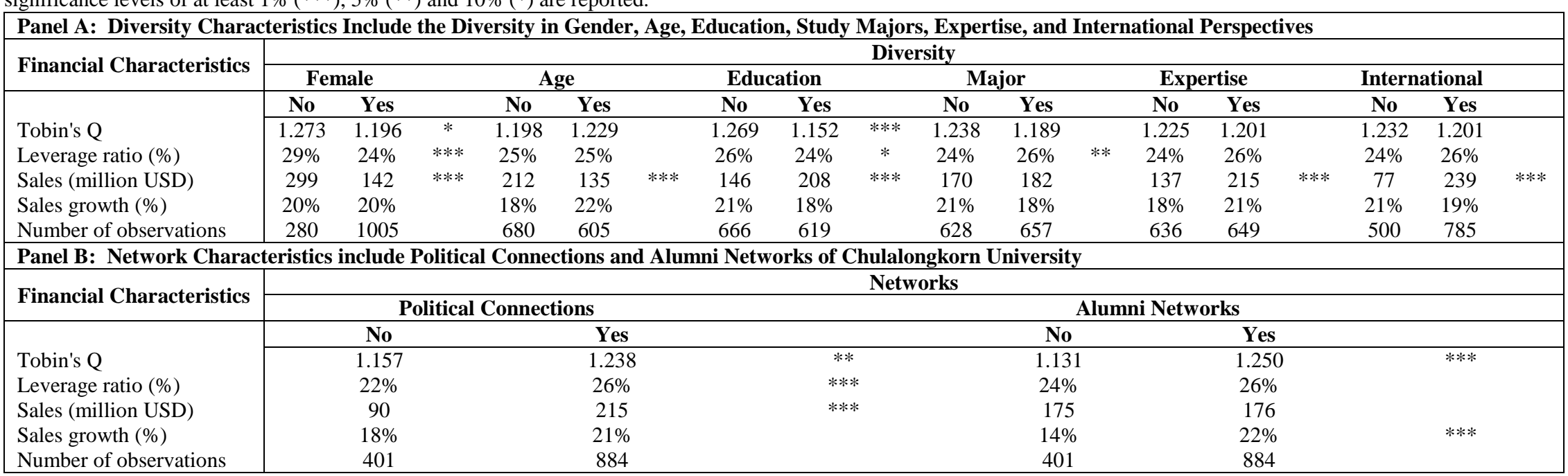

Note: The Bank of Thailand's foreign exchange reference rate is 41.91 baht per one US dollar over a period of 2001-2005. 


\section{Differences in Financial Characteristics: The Matter of Diversity and Network}

In the second part of our analysis, Panel A of Table 3 reports the differences in four financial characteristics, namely Tobin's Q ratio, leverage ratio, sales and sales growth, between two groups of firms using diversity measures. The results show that boards with diversity in gender, which is defined as a board with female directors, have lower Tobin's Q ratio and sales. It seems that boards with female directors are more conservative than those without female directors as shown by a lower leverage ratio. In terms of age diversity (measured by a dummy variable if the age diversity measure of a board is higher than that of the sample median), we find that boards with age diversity generate lower sales.

In addition, the findings show that the Tobin's Q ratio of boards with diverse educational levels (measured by a dummy variable if the education diversity measure of a board is higher than that of the sample median) is lower than those without education diversity. The results also show that boards with diverse educational levels have lower leverage ratio, but higher sales. Boards that are diverse in terms of study majors (measured by a dummy variable if the study major diversity measure of a board is higher than that of the sample median) have higher leverage ratio than those of non-diverse study major boards. Furthermore, we find that diversity in international perspectives (measured by a dummy variable if the proportion of directors studied abroad to that of directors studied only at local institutions is higher than 1) and expertise of boards (measured by a dummy variable if the expertise diversity measure of a board is higher than that of the sample median) also help firms generate higher sales.

The financial characteristics between boards with and without networks are demonstrated in Panel B of Table 3. We find that politically connected boards are valuable as reported by a higher Tobin's Q ratio. They also have higher sales and leverage ratio than those without political connections. Boards with alumni networks also create higher value to firms. Boards with a Chulalongkorn University $(\mathrm{CU})$ network have a higher Tobin's Q ratio than those without this prestigious university alumni network. We also find that their sales growth is higher.

\section{The Impact of Board Diversity and Networks on Firm Value}

In the final part of our analysis, Table 4 shows the impact of board diversity and networks on firm value. Model 1 presents the regression results of the effects of diversity on firm value. In addition to board diversity, we investigate the impact of board networks on firm value as shown in Model 2. In Model 3, we combine variables of board diversity and networks.

Focusing on board diversity, the results of Model 1 and Model 3 show no evidence to support the impact of gender diversity on firm value. Hence we reject Hypothesis 1 . These findings are consistent with Zahra \& Stanton (1988), Shrader, Blackburn, \& Iles (1997), and Rose (2007). Model 1 also shows the insignificant result of age diversity. However, in Model 3, age diversity becomes positively significant to firm value, which supports Hypothesis 2. The significance level is marginal, though. The significance of age diversity to firm value is in line with McIntyre \& Mitchell (2004) and Hagendorff \& Keasey (2012). In both Model 1 and 3, we find that diversity in educational levels leads to lower firm value. The significantly negative relationship between the diversity in educational levels and firm value indicates that Hypothesis 3 is rejected. In contrast, the firm value is positively associated to the diversity in study majors. Thus, we accept Hypothesis 4. Nevertheless, the results show that diversity in expertise and international perspectives of boards are not significant to firm value. Thus, we reject Hypothesis 5 and Hypothesis 6. 
Table 4: The Impact of Board Diversity and Network on Firm Value

The figures in parentheses report p-value for two-tailed tests. The statistical significance at levels of $1 \%(* * *), 5 \%(* *)$ and $10 \%$ $(*)$ is reported.

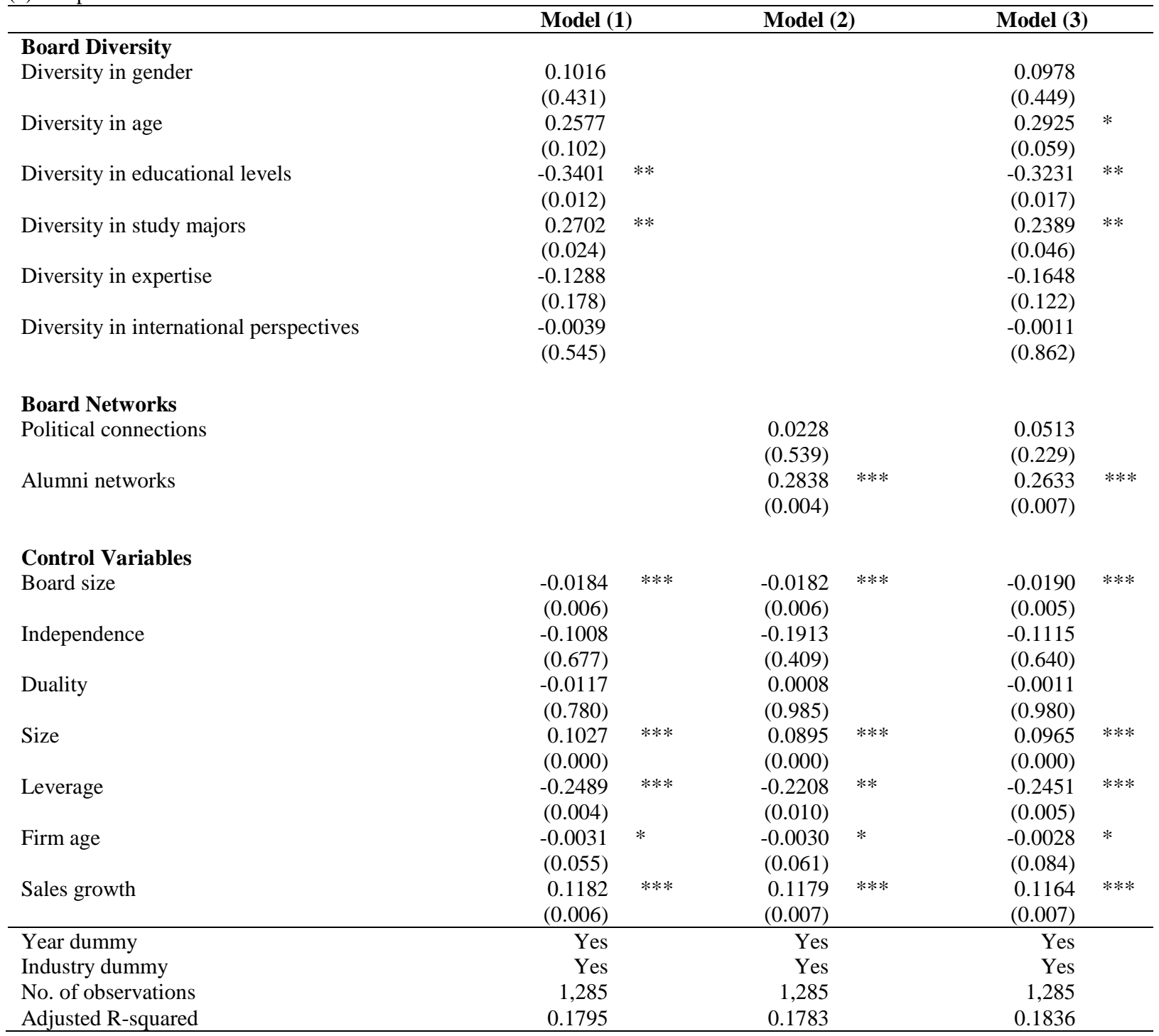

In addition to board diversity, we investigate the impact of board networks on firm value as shown in Model 2. We find no supporting evidence about the impact of political connections on firm value; thus, we reject Hypothesis 7. However, the value of firms is positively associated with the proportion of directors with an alumni network, therefore, we accept Hypothesis 8. The network of directors who were graduated from the oldest and arguably most prestigious university seems to be beneficial to Thai firms; this result is consistent with the findings of Siegel (2007). In Model 3, in which we combine variables of board diversity and networks, the effects of board networks on firm value remain significant as shown in Model 2.

Regarding the aspects of board composition as control variables, we find the influence of board size on firm value in all three models. The number of directors on a board is negatively related to firm value. This implies that large boards might adversely affect communication and coordination in Thai firms and might not play an effective monitoring role as documented by Lipton \& Lorsch (1992). Our findings concerning the impact of board size on firm value confirm the results of Eisenberg, Sundgren, \& Wells (1998) and Mak \& Kusnadi (2005). However, the impacts of board independence and CEO duality on firm value are not significant in this paper, which 
is similar to previous research (Chen, Lin, \& Yi, 2008; Dahya, Garcia, \& Van Bommel, 2009; Daily \& Dalton, 1997; Dalton, Daily, Ellstrand, \& Johnson, 1998).

The results of Model 1 to Model 3 also show that firm size and sales growth are positively associated to Tobin's Q ratio. The larger firms and firms with investment opportunity are more valuable. In contrast, we find that the leverage ratio and firm age are negatively related to firm value. The higher leverage ratio could lead to poor firm value, and the younger firms seem to have better growth opportunity to generate higher value.

In sum, we find that diversity in age, study majors and alumni network add value to firms. However, diverse educational levels of boards are detrimental to firm value. Our findings also show that diversity in gender, expertise and international perspectives, and the presence of political connections are not significantly related to firm value.

\section{CONCLUSION}

Boards of directors are one of the most important mechanisms of corporate governance to monitor and advise top management. In response to the financial crisis in 1997, the SET has recommended firms to appoint competent directors and has highlighted the importance of board diversity and composition. We investigate the board characteristics and their impact on firm value by introducing several measures of board diversity (gender, age, educational levels, study majors, professional expertise, and international perspectives) and networks (political connections and alumni networks).

The results show that the diversity in age and academic majors of Thai boards appears to be beneficial to firms, while diversity in educational levels adversely influences firm value. Although in 2006 Thai authorities developed detailed guidelines about board competencies, we find that Thai listed firms are concerned about the importance of director diversity in different dimensions after the Asian financial crisis. Our findings also confirm that networks are one of the key institutional characteristics in emerging markets. However, we find only the value of the alumni network of an elite university in Thailand, not those of political connections. Board composition (size, independence and CEO duality) was also included, and the results show that smaller board size is more valuable to Thai firms, suggesting a more effective monitoring role.

Our findings have important implications that diversity and networking of human resources, especially directors, are important for firms in today's dynamic and competitive business environment. Given similar features of corporate governance among Asian countries (Globerman, Peng, \& Shapiro, 2011), our results provide additional evidence for relevant authorities to widen their viewpoints about corporate governance practices and human resource development in Asia-Pacific region. In addition, the findings are consistent with the direction of the best practices in enhancing board competencies and director qualifications.

\section{ACKNOWLEDGEMENT}

Any remaining errors or omissions rest solely with the author(s) of this paper. The authors would like to acknowledge the Thailand Research Fund, the Office of the Higher Education Commission and Dhurakij Pundit University for their financial support (MRG5380274).

\section{AUTHOR INFORMATION}

Thitima Sitthipongpanich, Ph.D., is an Assistant Professor at Dhurakij Pundit University. She received her B.A. degree in Business Administration (Finance and Banking) from Thammasat University, her MBA from the Asian University of Science and Technology, her Master of Research (Finance) from the Lancaster University and her Ph.D. (Finance) from the University of Manchester. Her research interests include corporate finance and corporate governance. Her research has been published in academic journals such as Journal of Banking and Finance and International Research Journal of Finance and Economics. E-mail: thitima.sih@dpu.ac.th (Corresponding author) 
Piruna Polsiri, Ph.D., is the Investor Relations Head at Bangkok Metro Public Company Limited. She received her B.A. degree in Business Administration from Thammasat University, an MBA from the University of Texas at Arlington, and a Ph.D. from the University of Melbourne. Her research interests include corporate finance, corporate governance, and business groups. She did a project on corporate governance of banks in Asia with the Asian Development Bank Institute. She also wrote book chapters on the ownership structure of Thai listed firms and business groups in Thailand. E-mail: pirunab@bangkokmetro.co.th

\section{REFERENCES}

1. Adams, R. B., \& Ferreira, D. (2007). A theory of friendly boards. Journal of Finance, 62(1), 217-250.

2. Adams, R. B., \& Ferreira, D. (2009). Women in the boardroom and their impact on governance and performance. Journal of Financial Economics, 94(2), 291-309.

3. Agrawal, A., \& Knoeber, C. (2001). Do some outside directors play a political role? Journal of Law and Economics, 44(1), 179-198.

4. Anderson, R. C., Reeb, D. M., Upadhyay, A., \& Wanli, Z. (2011). The economics of director heterogeneity. Financial Management, 40(1), 5-38.

5. Baliga, B. R., Moyer, R. C., \& Rao, R. S. (1996). CEO duality and firm performance: What's the fuss? Strategic Management Journal, 17(1), 41-53.

6. Barber, B. M., \& Odean, T. (2001). Boys will be boys: Gender, overconfidence, and common stock investment. Quarterly Journal of Economics, 116(1), 261-292.

7. Baysinger, B. D., \& Butler, H. N. (1985). Corporate governance and the board of directors: Performance effects of changes in board composition. Journal of Law, Economics and Organization, 1(1), 101-124.

8. Bhagat, S., \& Black, B. (1999). The uncertain relationship between board composition and firm performance. Business Lawyer, 54(3), 921-963.

9. Bilimoria, D., \& Piderit, S. K. (1994). Board committee membership: Effects of sex-based bias. Academy of Management Journal, 37(5), 1453-1477.

10. Bonn, I. (2004). Board structure and firm performance: Evidence from Australia. Journal of the Australian and New Zealand Academy of Management, 10(1), 14-24.

11. Boone, A. L., Field, L. C., Karpoff, J. M., \& Raheja, C. G. (2007). The determinants of corporate board size and composition: An empirical analysis. Journal of Financial Economics, 85(1), 66-101.

12. Bunkanwanicha, P., \& Wiwattanakantang, Y. (2009). Big business owners in politics. Review of Financial Studies, 22(6), 2133-2168.

13. Byrnes, J. P., Miller, D. C., \& Schafer, W. D. (1999). Gender differences in risk taking: A meta-analysis. Psychological Bulletin, 125(3), 367-383.

14. Campbell, K., \& Mínguez-Vera, A. (2008). Gender diversity in the boardroom and firm financial performance. Journal of Business Ethics, 83(3), 435-451.

15. Carpenter, M. A., \& Westphal, J. D. (2001). The strategic context of external network ties: Examining the impact of director appointments on board involvement in strategic decision making. Academy of Management Journal, 44(4), 639-660.

16. Carter, D. A., Simkins, B. J., \& Simpson, W. G. (2003). Corporate governance, board diversity, and firm value. Financial Review, 38(1), 33-53.

17. Chen, C., Lin, B. J., \& Yi, B. (2008). CEO duality and firm performance: An endogenous issue. Corporate Ownership and Control, 6(1), 58-65.

18. Choi, J. J., Park, S. W., \& Yoo, S. S. (2007). The value of outside directors: Evidence from corporate governance reform in Korea. Journal of Financial and Quantitative Analysis, 42(04), 941-962.

19. Claessens, S., Djankov, S., \& Lang, L. (2000). The separation of ownership and control in East Asian corporations. Journal of Financial Economics, 58(1-2), 81-112.

20. Cox, T. H., Lobel, S. A., \& McLeod, P. L. (1991). Effects of ethnic group cultural differences on cooperative and competitive behavior on a group task. Academy of Management Journal, 34(4), 827-847.

21. Dahya, J., Garcia, L. G., \& Van Bommel, J. (2009). One man two hats: What's all the commotion! Financial Review, 44(2), 179-212.

22. Daily, C. M., \& Dalton, D. R. (1997). CEO and board chair roles held jointly or separately: Much ado about nothing? Academy of Management Executive, 11(3), 11-20. 
23. Dalton, D. R., Daily, C. M., Ellstrand, A. E., \& Johnson, J. L. (1998). Meta-analytic reviews of board composition, leadership structure, and financial performance. Strategic Management Journal, 19(3), 269290.

24. Eckel, C. C., \& Grossman, P. J. (2008). Men, women and risk aversion: Experimental evidence. In R. P. Charles \& V. L. Smith (Eds.), Handbook of Experimental Economics Results (Vol. 1, pp. 1061-1073): Elsevier.

25. Eisenberg, T., Sundgren, S., \& Wells, M. T. (1998). Larger board size and decreasing firm value in small firms. Journal of Financial Economics, 48(1), 35-54.

26. Erhardt, N. L., Werbel, J. D., \& Shrader, C. B. (2003). Board of director diversity and firm financial performance. Corporate Governance: An International Review, 11(2), 102-111.

27. Espenlaub, S., Khurshed, A., \& Sitthipongpanich, T. (2012). Bank connections, corporate investment and crisis. Journal of Banking and Finance, 36(5), 1336-1353.

28. Fan, J. P. H., Wong, T. J., \& Zhang, T. (2007). Politically connected CEOs, corporate governance, and Post-IPO performance of China's newly partially privatized firms. Journal of Financial Economics, 84(2), 330-357.

29. Filatotchev, I., Jackson, G., \& Nakajima, C. (2012). Corporate governance and national institutions: A review and emerging research agenda. Asia Pacific Journal of Management, doi: 10.1007/s10490-1001219293-10499.

30. Globerman, S., Peng, M., \& Shapiro, D. (2011). Corporate governance and Asian companies. Asia Pacific Journal of Management, 28(1), 1-14.

31. Hagendorff, J., \& Keasey, K. (2012). The value of board diversity in banking: Evidence from the market for corporate control. European Journal of Finance, 18(1), 41-58.

32. Hermalin, B. E., \& Weisbach, M. S. (1991). The effects of board composition and direct incentives on firm performance. Financial Management, 20(4), 101-112.

33. Hermalin, B. E., \& Weisbach, M. S. (2003). Boards of directors as an endogenously determined institution: A survey of the economic literature. Economic Policy Review 9(1), 7-26.

34. Herrmann, P., \& Datta, D. K. (2002). CEO successor characteristics and the choice of foreign market entry mode: An empirical study. Journal of International Business Studies, 33(3), 551-569.

35. Hillman, A. J., \& Dalziel, T. (2003). Boards of directors and firm performance: Integrating agency and resource dependence perspectives. Academy of Management Review, 28(3), 383-396.

36. Hsu, H. (2010). The relationship between board characteristics and financial performance: An empirical study of United States initial public offerings. International Journal of Management, 27(2), 332-341.

37. Jianakoplos, N. A., \& Bernasek, A. (1998). Are women more risk averse? Economic Inquiry, 36(4), 620630 .

38. Jiang, Y., \& Peng, M. (2011). Are family ownership and control in large firms good, bad, or irrelevant? Asia Pacific Journal of Management, 28(1), 15-39.

39. Johnson, J. E. V., \& Powell, P. L. (1994). Decision making, risk and gender: Are managers different? British Journal of Management, 5(2), 123-138.

40. Kang, E., Ding, D. K., \& Charoenwong, C. (2009). Investor reaction to women directors. Journal of Business Research, 63(8), 888-894.

41. Kaplan, S. N., \& Minton, B. A. (1994). Appointments of outsiders to Japanese boards: Determinants and implications for managers. Journal of Financial Economics, 36(2), 225-258.

42. Kauer, D., Prinzessin zu Waldeck, T. C., \& Schaffer, U. (2007). Effects of top management team characteristics on strategic decision making. Management Decision, 45(6), 942-967.

43. Khwaja, A. I., \& Mian, A. (2005). Do lenders favor politically connected firms? Rent provision in an emerging financial market. Quarterly Journal of Economics, 120(4), 1371-1411.

44. Kiel, G. C., \& Nicholson, G. J. (2003). Board composition and corporate performance: How the Australian experience informs contrasting theories of corporate governance. Corporate Governance: An International Review, 11(3), 189-205.

45. Kim, H., \& Lim, C. (2010). Diversity, outside directors and firm valuation: Korean evidence. Journal of Business Research, 63(3), 284-291.

46. Klein, A. (1998). Firm performance and board committee structure. Journal of Law and Economics, 41(1), 275-304. 
47. Koufopoulos, D., Zoumbos, V., Argyropoulou, M., \& Motwani, J. (2008). Top management team and corporate performance: a study of Greek firms. Team Performance Management, 14(7/8), 340-363.

48. La Porta, R., Lopez de Silanes, F., \& Shleifer, A. (1999). Corporate ownership around the world. Journal of Finance, 54(2), 471-517.

49. Leblanc, R., \& Gillies, J. (2005). Inside the board room: How boards really work and the coming revolution in corporate governance. Ontario Canada: John Wiley \& Son.

50. Lenney, E. (1977). Women's self-confidence in achievement settings. Psychological Bulletin, 84(1), 1-13.

51. Letendre, L. (2004). The dynamics of the boardroom. Academy of Management Executive, 18(1), 101-104.

52. Lipton, M., \& Lorsch, J. (1992). A modest proposal for improved corporate governance. Business Lawyer, 48(1), 59-77.

53. Mak, Y. T., \& Kusnadi, Y. (2005). Size really matters: Further evidence on the negative relationship between board size and firm value. Pacific-Basin Finance Journal, 13(3), 301-318.

54. McIntyre, M. L., \& Mitchell, P. (2004). Board member demographics and firm performance: Carleton University.

55. Mehran, H. (1995). Executive compensation structure, ownership, and firm performance. Journal of Financial Economics, 38(2), 163-184.

56. Milliken, F. J., \& Martins, L. L. (1996). Searching for common threads: Understanding the multiple effects of diversity in organizational groups. Academy of Management Review, 21(2), 402-433.

57. Miwa, Y., \& Ramseyer, J. M. (2005). Who appoints them, What do they do? Evidence on outside directors from Japan. Journal of Economics and Management Strategy, 14(2), 299-337.

58. Nicholson, G. J., \& Kiel, G. C. (2007). Can directors impact performance? A case based test of three theories of corporate governance Corporate Governance: An International Review 15(4), 585-608.

59. Norburn, D. (1986). Gogos, yoyos and dodos: Company directors and industry performance. Strategic Management Journal, 7(2), 101-117.

60. Palmer, D., \& Barber, B. M. (2001). Challengers, elites, and owning families: A social class theory of corporate acquisitions in the 1960s. Administrative Science Quarterly, 46(1), 87-120.

61. Peng, M. W. (2004). Outside directors and firm performance during institutional transitions. Strategic Management Journal, 25(5), 453-471.

62. Peng, M. W., Au, K., \& Wang, D. (2001). Interlocking directorates as corporate governance in Third World multinationals:Theory and evidence from Thailand. Asia Pacific Journal of Management, 18(2), 161-181.

63. Peng, M. W., Buck, T., \& Filatotchev, I. (2003). Do outside directors and new managers help improve firm performance? An exploratory study in Russian privatization. Journal of World Business, 38(4), 348-360.

64. Pfeffer, J. (1972). Size and composition of corporate boards of directors: The organization and its environment. Administrative Science Quarterly, 17(2), 218-228.

65. Pfeffer, J., \& Salancik, G. R. (1978). The external control of organisations: A resource dependence perspective. New York: Harper and Row.

66. Raheja, C. G. (2005). Determinants of board size and composition: A theory of corporate boards. Journal of Financial and Quantitative Analysis, 40(2), 283-306.

67. Rose, C. (2007). Does female board representation influence firm performance? The Danish evidence. Corporate Governance: An International Review, 15(2), 404-413.

68. Shrader, C. B., Blackburn, V. B., \& Iles, P. (1997). Women in management and firm financial performance: An exploratory study. Journal of Managerial Issues, 9(3), 355-372.

69. Siegel, J. (2007). Contingent political capital and international alliances: Evidence from South Korea. Administrative Science Quarterly, 52(4), 621-666.

70. Yermack, D. (2006). Board members and company value. Financial Markets and Portfolio Management, 20(1), 33-47.

71. Zahra, S. A., \& Stanton, W. W. (1988). The implications of board of directors composition for corporate strategy and performance. International Journal of Management, 5(2), 229-236. 


\section{NOTES}

